\title{
Response of domestic chickens to fasting and non-fast moulting programmes in a humid tropical environment
}

${ }^{* 1}$ Ogbu, C. C., ${ }^{2}$ Ndifereke, S., ${ }^{3}$ Ogbu, N. N.and ${ }^{1}$ Okoli, I. C.

${ }^{\prime}$ Department of Animal Health and Production, College of Veterinary Medicine, Michael Okpara University of Agriculture, Umudike, Abia State, Nigeria. ${ }^{2}$

Department of Animal Science, University of Nigeria, Nsukka, Enugu State.

${ }^{3}$ Department of Animal Physiology and Genetics,

College of Animal Science and Animal Production,

Michael Okpara University of Agriculture, Umudike, Abia State, Nigeria.

\begin{abstract}
Corresponding author: coschi07@yahoo.com
The study evaluates the effect of fasting and non-fasting (Zn supplementation) moulting methods on performance of indigenous (IC) and Shaver brown (SB) hens in the hot humid tropical environment of Nsukka, Southeastern Nigeria. One hundred and twenty indigenous and Shaver brown hens (60/genotype) aged between 75 and 80 weeks were shared into three groups (20/group), $T_{1}$ : hens fed layers diet at $125 \mathrm{~g} /$ bird/day (control group), $T_{2}$ : hens fed layers mash supplemented with 20,000ppm Zn as ZnO at $125 \mathrm{~g} /$ bird/day for 14 days, and $T_{3}$ : hens subjected to feed deprivation (FD) for 14 days. Water was given ad libitum to all birds. Data analyzed were pre-moult and moulting body weight, hen day egg production (HDEP), and egg weight. Moulting method significantly $(p<0.05)$ affected body weight in SB but not in indigenous hens; hen day egg production and day to stoppage of egg production in both genotypes with FD resulting in greater loss in body weight and an early cessation of egg production compared to zinc supplementation. Shaver Brown hens subjected to ZnO and FD lost 15.6 and $26.7 \%$ of their initial body weight, respectively while IC lost 16.2 and $32.6 \%$, respectively. Hen day egg production was $0.00 \pm 0.00 \%$ in the last week of moulting in $S B$ and IC moulted by FD but $8.32 \pm 6.47 \%$ for SB and $10.71 \pm 3.25 \%$ for IC moulted by ZnO. Egg production stopped on day 10 (D10) and 6 in SB hens submitted to ZnO and FD, respectively and on D13 and 5, respectively for the IC. In conclusion, zinc supplementation at 20,000ppm in the diet of laying chickens as moulting agent is a milder but equally effective moulting method as fasting and is recommended for intensive commercial and rural indigenous poultry production.
\end{abstract}

Keywords: Induced moulting, body weight loss, egg production, Shaver Brown, local chickens.

\section{Introduction}

Egg production in laying flocks is limited by age and decreases as hen ages. The aging process and cessation of egg production initiate natural moulting which usually lasts for about 4 months (Santos et al., 2014). Moulting is therefore a major event in the annual life cycle of the domestic chicken and other avian species (Aygun and Olgun, 2010). Commercial egg producers in countries where the disposal of spent hens incurs additional costs to the farmer employ induced moulting to circumvent natural moulting and to induce spent hens to rapidly enter a second laying cycle thereby extending the laying flock performance (North and Bell 1990; Aygun and Olgun, 2010). Induced moulting rejuvenates the hen's reproductive organs and improves the post-moult performance of the flock in livability, egg production, and egg quality compared to the immediate pre-moult performance (Holt, 2003; Webster, 2003). Programmes used to induce moulting in laying hens include feed deprivation, photoperiod reduction, mineral $(\mathrm{Ca}, \mathrm{Cu}$, 


\section{Response of domestic chickens to fasting and non-fast moulting programmes}

$\mathrm{Zn}, \mathrm{Al}$, etc) supplementation and the use of low energy diets (Molino et. al., 2009; Santos et al., 2014). These schemes cause total cessation of egg production, shading of body fat, and renewal (involution) of the reproductive organs (Hussen, 1996; Santos et al., 2014). Feed deprivation was the primary method of induced moulting in hens (Gast and Ricke, 2003; Aygun and Olgun, 2010). Other moulting techniques were developed in response to welfare and public health concerns associated with fast moulting of birds (Ricke et al., 2001; Yousaf and Ahmed, 2006). Moulting by Zn supplementation seems particularly attractive because zinc is an important micro mineral, and has been shown to possess immune-potentiating and antioxidant effects (Ogbu et al., 2016).

Induced moulting of birds has received limited attention in sub-Saharan Africa including Nigeria. The practice is virtually nonexistent in rural poultry production in which indigenous chickens constitute $70-$ $80 \%$ of the flock. This is probably due to lack of awareness of the economic gains derivable from moulting aged flocks. Indigenous poultry farmers hence endure long periods of natural moulting with the attendant losses of revenue. For the commercial poultry industry employing exotic breeds, induced moulting is not practiced due partly to lack of awareness and probably because sale of spent hens is not a big challenge. However, when due to disease challenge, scarcity of chicks or other constraints a farmer is not able to raise replacement stock, the laying flock is kept longer than usual without being force moulted even when productivity is marginal. The practice of induced moulting could be very beneficial to poultry farmers in Nigeria. Apart from extending the productive and economic life of the hen, enabling higher revenue to the farmer, it could enable farmers to (1) purchase day old chicks or point of lay at ease and at competitive prices as recycling of flocks will reduce the demand for day old chicks, and point of lay pullets (Aygun and Olgun, 2010), (2) reduce the frequency of brooding and rearing of young chicks in the farm and thereby minimize the anxiety associated with the brooding phase, (3) save the time needed for brooding and rearing a new replacement flock, and (4) reduce disease challenge in farms and avoid the costs associated with frequent vaccination and medication incurred during brooding and rearing (Moustafa et al., 2010). Aygun and Olgun (2010) observed that induced moulting is an important tool for the economic management of laying flocks. Many studies have evaluated the response of exotic hens to moulting programmes but there is limited information on the response of indigenous and exotic hens to the same moulting methods. The present study was therefore conceived to evaluate and compare the performance of indigenous and Shaver brown hens during forced moulting using a fasting and non-fasting moulting programmes.

\section{Materials and methods}

The study was carried out at the Poultry Unit of the teaching and research farm of the Department of Animal Science, Faculty of Agriculture, University of Nigeria, Nsukka. One hundred and twenty local and Shaver Brown chickens (60/genotype) aged $75-80$ weeks old were used for the study. The birds were shared into three treatment groups $(\mathrm{T})$ namely: birds fed layers diet at $125 \mathrm{~g} / \mathrm{bird} /$ day or control group $\left(\mathrm{T}_{1}\right)$, birds fed layers mash supplemented with 20,000ppm zinc as $\mathrm{ZnO}$ (El-Deek and Al-Harthi 2004) for 14 days at $125 \mathrm{~g} / \mathrm{bird} /$ day $\left(\mathrm{T}_{2}\right)$, and birds subjected to feed deprivation for 14 days $\left(\mathrm{T}_{3}\right)$. Water was provided ad libitum to birds belonging to each treatment. The experimental groups 


\section{Ogbu, Ndifereke, Ogbu N.and Okoli}

were evaluated for body weight, egg production, and egg weight before induction of moulting (pre-moult), and for 14 days during moulting treatment.

\section{Statistical analysis}

Data were subjected to analysis of variance in completely randomized design to compare between treatment groups while comparison between genotypes was by independent samples t-test.

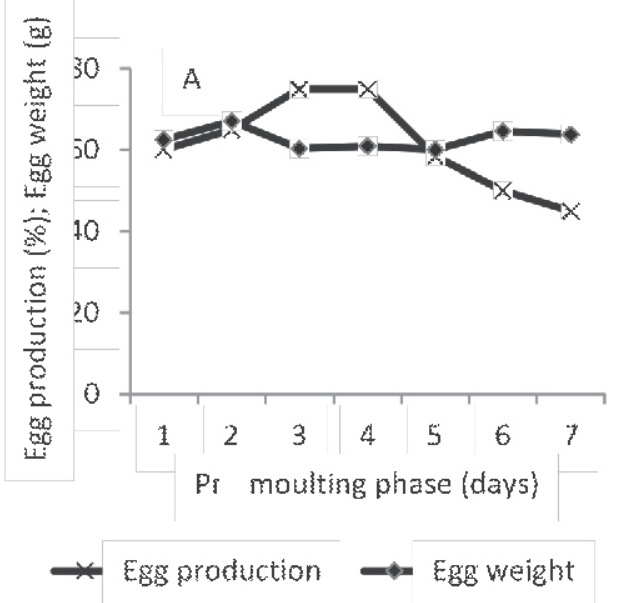

\section{Result and discussion}

Trend in performance of hens pre-moult

Highest hen day egg production (HDEP) was $75 \%$ in Shaver Brown hens before moulting and this was observed on days 3 (D3) and 4, respectively in the one week pre-moult (Fig. 1, panel A) however, HDEP ranged between 45 to $75 \%$ within this period in hens of this breed subjected to $\mathrm{ZnO}$ treatment but 52 to $60 \%$ in those of FD.

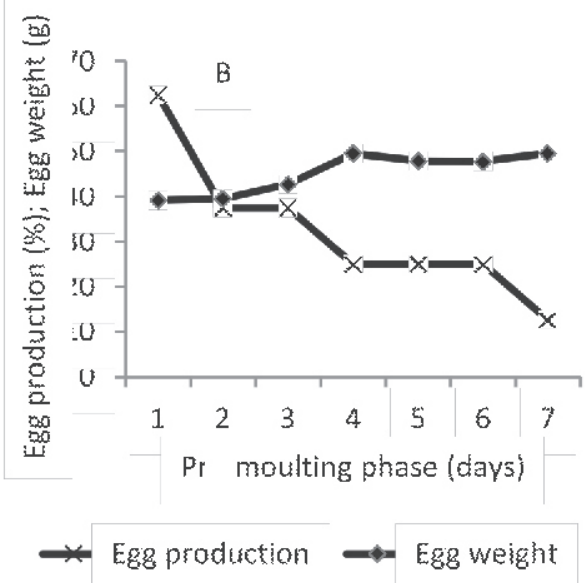

Fig. 1: Egg production and egg weight of Shaver brown (panel A) and indigenous hens (panel B) before moulting.

For the indigenous hens (Fig. 1, panel B), HDEP in the last week before moulting ranged between 12.5 to $62.5 \%$ for $\mathrm{ZnO}$ group and 40 to $80 \%$ for those of FD. Fig. 1 also shows that HDEP decreased gradually in SB but rapidly in local chickens. Egg weight did not fluctuate as much as egg production and showed some improvement as egg production decreased in the two genotypes. Body weight ranged between 1.50 and $1.95 \mathrm{~kg}$ and 1.45 and $1.90 \mathrm{~kg}$ in SB hens belonging to $\mathrm{ZnO}$ and $\mathrm{FD}$ groups, respectively. The corresponding values for indigenous hens were 1.00 and $1.80 \mathrm{~kg}$ and 1.25 and $1.60 \mathrm{~kg}$, respectively. Hens are usually forced to moult towards the end of their first laying cycle due to ageing and poor egg production (Moustafa et al., 2010; Santos et al., 2014). In Nigeria, such flocks are disposed and replaced with new stocks. In advanced economies other conditions that force farmers to moult laying flocks include poor egg sales compounded by high feed costs. The birds employed in the present study were 75 to 80 weeks old and showed declining laying performance such that they had become uneconomical to rear. These situations support the disposal and replacement of the flock or induction of moulting to bring the birds into a second laying cycle (Webster, 2003) and avoid flock replacement costs (El-Deek and AlHarthi, 2004). 


\section{Response of domestic chickens to fasting and non-fast moulting programmes}

Trend in performance of hens during the moulting phase

The trend in performance traits of SB and indigenous hens during moulting is presented in Tables 1 and 2, respectively.

Table 1: Trend in performance of Shaver Brown hens during moulting

\begin{tabular}{llll}
\hline Shaver brown & Body weight $(\mathrm{g})$ & Egg production $(\%)$ & Egg weight $(\mathrm{g})$ \\
\hline $\begin{array}{l}\text { ZnO supplementation } \\
\text { Initial (before }\end{array}$ & $1.67 \pm 0.05^{\mathrm{a}}$ & $61.19 \pm 6.16^{\mathrm{a}}$ & $62.70 \pm 1.05$ \\
moulting) & & & \\
$\mathrm{WK}_{1}$ & $1.43 \pm 0.05^{\mathrm{b}}$ & $30.73 \pm 6.46^{\mathrm{b}}$ & $63.91 \pm 1.05$ \\
$\mathrm{WK}_{2}$ & $1.41 \pm 0.06^{\mathrm{b}}$ & $8.32 \pm 7.65^{\mathrm{c}}$ & $62.40 \pm 1.25$ \\
Feed deprivation (FD) & & & \\
Initial & $1.62 \pm 0.07^{\mathrm{a}}$ & $58.14 \pm 6.52^{\mathrm{a}}$ & $62.49 \pm 0.69$ \\
$\mathrm{WK}_{1}$ & $1.29 \pm 0.07^{\mathrm{b}}$ & $28.57 \pm 6.52^{\mathrm{b}}$ & $63.89 \pm 0.69$ \\
$\mathrm{WK}_{2}$ & $1.18 \pm 0.07^{\mathrm{b}}$ & $0.00 \pm 0.00^{\mathrm{c}}$ & - \\
$\mathrm{Control}$ & & & \\
Initial & $1.63 \pm 0.04^{\mathrm{b}}$ & $60.00 \pm 6.97$ & $58.80 \pm 1.38$ \\
$\mathrm{WK}_{1}$ & $1.67 \pm 0.04^{\mathrm{ab}}$ & $62.14 \pm 6.97$ & $60.70 \pm 1.38$ \\
$\mathrm{WK}_{2}$ & $1.76 \pm 0.04^{\mathrm{a}}$ & $59.29 \pm 6.97$ & $60.04 \pm 1.38$ \\
\hline
\end{tabular}

WK: week; a-c: means on the same column with different superscripts are significantly different $(\mathrm{p}<0.05)$

Shaver Brown hens fed diet supplemented with $\mathrm{ZnO}$ decreased in body weight from $1.67 \pm 0.05 \mathrm{~kg}$ to $1.43 \pm 0.05 \mathrm{~kg}$ in wk 1 ( $14.37 \%$ loss) and to $1.41 \pm 0.06 \mathrm{~kg}$ by the end of wk 2 resulting in a cumulative body weight loss of $15.57 \%$. For those subjected to FD, body weight loss was $27 \%$ by the end of moulting (Table 1). Indigenous hens fed $\mathrm{ZnO}$ decreased in body weight from
$1.36 \pm 0.10 \mathrm{~kg}$ at onset of moulting treatment to $1.14 \pm 0.11 \mathrm{~kg}$ at the end of moulting with body weight loss of $16.2 \%$ whereas those subjected to FD decreased in body weight from $1.38 \pm 0.18 \mathrm{~kg}$ to $1.05 \pm$ $0.18 \mathrm{~kg}$ or a loss of $24 \%$ in wk 1 and to $0.93 \pm$ $0.16 \mathrm{~kg}$ by end of wk 2 or a cumulative loss of $32.6 \%$ (Table 2 ).

Table 2: Trend in performance of indigenous hens during moulting

\begin{tabular}{llll}
\hline & Body weight $(\mathrm{g})$ & Egg production $(\%)$ & Egg weight $(\mathrm{g})$ \\
\hline ZnO supplementation & & & \\
Initial & $1.36 \pm 0.10$ & $32.14 \pm 6.25^{\mathrm{a}}$ & $45.19 \pm 2.02$ \\
$\mathrm{WK}_{1}$ & $1.27 \pm 0.10$ & $37.50 \pm 6.25^{\mathrm{a}}$ & $43.36 \pm 2.02$ \\
$\mathrm{WK}_{2}$ & $1.14 \pm 0.11$ & $12.50 \pm 6.25^{\mathrm{b}}$ & $40.77 \pm 2.18$ \\
Feed deprivation & & & \\
Initial & $1.38 \pm 0.10$ & $60.00 \pm 5.39^{\mathrm{a}}$ & $41.52 \pm 0.67$ \\
$\mathrm{WK}_{1}$ & $1.05 \pm 0.10$ & $40.00 \pm 6.03^{\mathrm{b}}$ & $42.10 \pm 0.75$ \\
$\mathrm{WK}_{2}$ & $0.93 \pm 0.09$ & $0.00 \pm 0.00^{\mathrm{c}}$ & - \\
Control & & \\
Initial & $1.08 \pm 0.08$ & $35.71 \pm 5.71$ & $43.70 \pm 1.70$ \\
$\mathrm{WK}_{1}$ & $0.97 \pm 0.08$ & $25.71 \pm 5.71$ & $39.34 \pm 1.70$ \\
$\mathrm{WK}_{2}$ & $0.92 \pm 0.08$ & $35.71 \pm 5.71$ & $39.34 \pm 1.70$ \\
\hline
\end{tabular}

WK: week; a-c: means on the same column with different superscripts are significantly different $(\mathrm{p}<0.05)$ 


\section{Ogbu, Ndifereke, Ogbu N.and Okoli}

Shaver Brown hens in the control group showed significant increase in body weight at the end of the treatment while the local hens were not affected. The observed range of decreases in body weight in the moulted groups agreed considerably with values reported by other studies. For instance, AlKirkuki (2012) reported body weight losses of between 9.3 and $17.8 \%$ over 9 days of moulting in broiler breeders fed between 15,000 and 25,000 ppm zinc. El-Deek and Al-Harthi (2004) reported body weight loss of $16 \%$ within 14 days of moulting in hens fed $2 \% \mathrm{ZnO}$ and a loss of $21 \%$ of the body weight in those fed $3 \% \mathrm{ZnO}$, or subjected to fasting moult. Park et al. (2004) reported body weight loss of 15.52 and $15.60 \%$ over 9 days in laying hens moulted with zinc acetate and zinc propionate, respectively while those subjected to feed withdrawal lost $25.12 \%$ of their body weight within the same period. Molino et al. (2009) observed body weight loss of $21.19 \%$ by D 7 in hens undergoing fasting moult which agreed with the result of the present study. Whatever the moulting method employed, body weight loss of 25 to $30 \%$ has been advocated to optimize post moult performance (Sohail et al., 2011). Berry (2003) however observed that body weight loss of up to $31 \%$ improved post moult performance but suggested that a loss of more than $35 \%$ may be detrimental on life of flock egg production due to long recovery period when no eggs are produced. In the execution of moulting in laying hens, achievement of target percent body weight loss and/or the time for complete cessation of egg production has determined the duration of moulting treatment (Berry, 2003; Reddy et al., 2008; Sohail et al., 2011). In the present study highest body weight losses in the moulted groups occurred in the first week of moulting and this agrees with Webster (2003) that phase one of physiological response to moulting treatment lasts for about 3.5 days and is characterized by rapid decrease in body weight followed by the phase of rapid reduction in rate of body mass loss. Moustafa et al. (2010) observed body weight loss of $10.1 \%$ on first day of fasting out of a total body weight loss of $25.2 \%$ in 16 days. Indigenous hens subjected to moulting showed the highest body weight losses probably as a result of their lower adipose tissue. Generally, percent body weight loss varies according to breed of bird, moulting diet, duration of moulting and environmental conditions such as ambient temperature (Santos et al., 2014). In the present study, HDEP decreased significantly $(\mathrm{p}<0.05)$ from pre-moult value of $61.19 \pm 6.16 \%$ to $8.32 \pm 7.65 \%$ in wk 2 while egg weight was not significantly affected in SB hens subjected $\mathrm{ZnO}$ treatment (Table 1). In those moulted by FD, HDEP decreased to $28.57 \pm 6.52 \%$ after one week and to $0.00 \%$ in wk 2 while egg weight remained unchanged. For the indigenous hens (Table 2), HDEP decreased to $12.5 \pm 6.25 \%$ by wk 2 in the $\mathrm{ZnO}$ group and from $60 \%$ pre-moult to 40 $\%$ in wk 1 and subsequently to $0.00 \%$ in wk 2 in those of FD. Again egg weight was not significantly affected. For the control groups, HDEP and egg weight was not significantly affected in both genotypes. In the study by El-Deek and Al-Harthi (2004) HDEP decreased from $46 \%$ pre-moult to an average of $20.36 \%$ (loss of $25.64 \%)$ in wk 1 and to $1.3 \%$ (loss of $44.7 \%$ ) in wk 2 in hens moulted by $2 \% \mathrm{ZnO}$ supplementation and from $46 \%$ to $11.6 \%$ (loss of $34.4 \%$ ) in wk 1 and to $0.2 \%$ (loss of $45.8 \%$ ) in wk 2 for hens fed $3 \% \mathrm{ZnO}$. For hens subjected to fasting moult HDEP decreased from $46 \%$ to $13.7 \%$ (loss of $32.3 \%$ ) in wk 1 and $0.0 \%$ (loss of $46 \%$ ) in wk 2. These observations agreed with our results of 30.46, and 29.57 $\%$ loss in HDEP in wk 1 in SB hens treated with $\mathrm{ZnO}$, and $\mathrm{FD}$, respectively but lower 


\section{Response of domestic chickens to fasting and non-fast moulting programmes}

than the cumulative losses in wk 2 as a result of the higher initial (pre-moult) HDEP of the flocks employed in the present study.
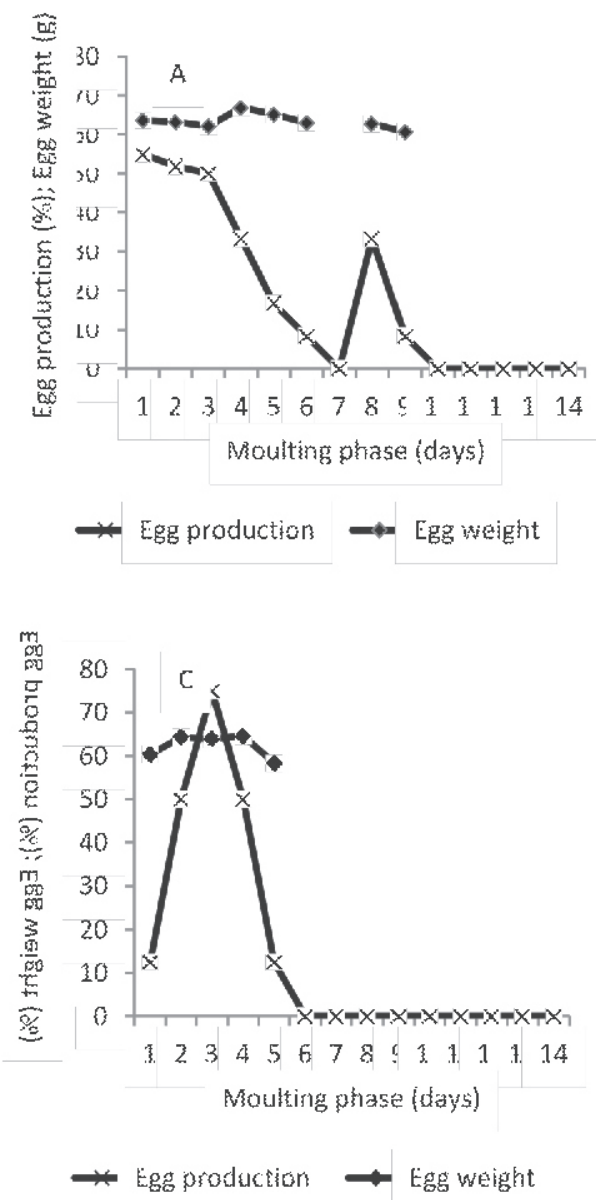

The trend in HDEP of Shaver Brown and indigenous hens subjected to different moulting techniques is presented in Fig. 2.
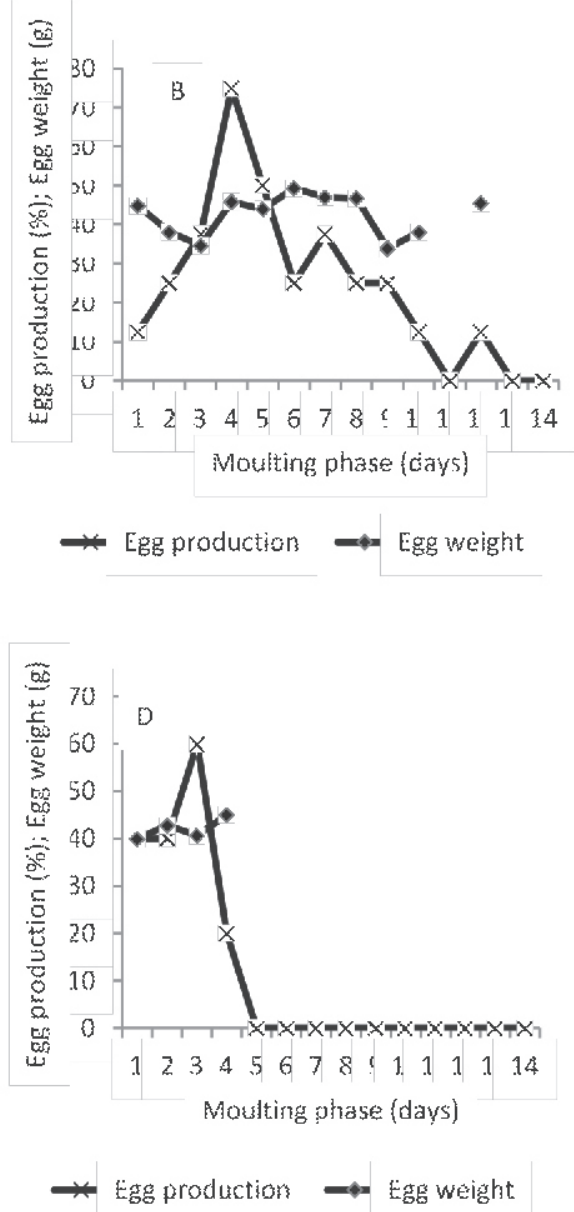

Fig. 2: Egg production and egg weight of Shaver brown and indigenous hens subjected to moulting by $\mathrm{ZnO}$ supplementation (panel A: Shaver brown; panel B: indigenous hens) and by Feed deprivation (panel C: Shaver brown; panel D: indigenous hens).

Shaver Brown hens treated with $\mathrm{ZnO}$ stopped laying on day (D) 10 of moulting treatment (Fig. 2, panel A) while their indigenous counterparts stopped laying on D 13 (panel B). For the group subjected to FD, SB and indigenous hens stopped laying on D 6, and 5, respectively (panel C, and D, respectively). In the two moulting treatments, egg weight fluctuated more in the indigenous hens compared to SB hens. Stoppage of egg production in moulting hens indicates reproductive quiescence and is used to determine duration of moulting (Gjorgovska et al., 2012; Santos et al., 2014). The observed number of days to stoppage of lay in birds fed $\mathrm{ZnO}$ agreed with 


\section{Ogbu, Ndifereke, Ogbu N.and Okoli}

El-Deek and Al-Harthi (2004) who reported D 11 in hens fed $2 \% \mathrm{ZnO}$, and D 10 in those fed $3 \% \mathrm{ZnO}$. The results are however at variance with the 3.89 days reported by Sgavioli et al. (2013) for hens fed 28,000 ppm $\mathrm{Zn}$ and 25 days observed in Cornish hens, and 22 days in Rock hens fed 25,000 ppm $\mathrm{ZnO}$, respectively as reported by Reddy et al. (2008). For hens subjected to FD, our findings disagreed with the 8 days reported by El-Deek and Al-Harthi (2004), 14 days reported by Reddy et al. (2008) in Cornish and Rock hens, respectively and 3.44 days reported by Sgavioli et al. (2013) probably as a result of differences in breed of birds, moulting diet and/or study environment.

\section{Effect of moulting technique on performance of laying chickens during moulting}

The effect of moulting methods on the performance of the experimental birds is presented in Table 3 for SB and Table 4 for indigenous chickens. Shaver Brown hens subjected to FD had significantly $(\mathrm{p}<0.05)$ lower body weight at the end of moulting compared to those moulted by $\mathrm{ZnO}$ while hens in the control group had the highest body weight (Table 3). No significant differences in body weight were observed between indigenous hens moulted by different methods and between moulted and unmoulted hens (Table 4). Hen day egg production differed significantly $(\mathrm{p}<0.05)$ between hens subjected to different moulting methods and between moulted and unmoulted groups in each genotype being $0.00 \pm 0.00 \%$ by the end of moulting in SB and indigenous hens moulted by FD compared to $8.32 \pm 6.47 \%$ for SB and 10.71 $\pm 3.25 \%$ for indigenous hens moulted by $\mathrm{ZnO}$, and $59.29 \pm 5.47 \%$ for $\mathrm{SB}$ and $35.71 \pm$ $3.25 \%$ for indigenous hens in the control group. Egg weight was similar across treatment groups.

Table 3: Effect of moulting methods on performance of Shaver Brown chickens during the moulting period

\begin{tabular}{llll}
\hline & \multicolumn{3}{l}{ Moulting method } \\
\hline Shaver brown & ZnO & FD & Control \\
\hline Body weight (kg) & & & \\
Initial & $1.67 \pm 0.06$ & $1.61 \pm 0.05$ & $1.63 \pm 0.05$ \\
$\mathrm{WK}_{1}$ & $1.43 \pm 0.07^{\mathrm{b}}$ & $1.29 \pm 0.06^{\mathrm{b}}$ & $1.67 \pm 0.06^{\mathrm{a}}$ \\
$\mathrm{WK}_{2}$ & $1.41 \pm 0.06^{\mathrm{b}}$ & $1.18 \pm 0.05^{\mathrm{c}}$ & $1.76 \pm 0.05^{\mathrm{a}}$ \\
Egg production (\%) & & & \\
Initial & $66.67 \pm 5.91$ & $58.14 \pm 5.00$ & $60.00 \pm 5.00$ \\
$\mathrm{WK}_{1}$ & $41.36 \pm 9.66^{\mathrm{ab}}$ & $28.57 \pm 8.16^{\mathrm{b}}$ & $62.14 \pm 8.16^{\mathrm{a}}$ \\
$\mathrm{WK}_{2}$ & $8.32 \pm 6.47^{\mathrm{b}}$ & $0.00 \pm 0.00^{\mathrm{c}}$ & $59.29 \pm 5.47^{\mathrm{a}}$ \\
Egg weight (g) & & \\
Initial & $62.60 \pm 0.47^{\mathrm{a}}$ & $62.49 \pm 0.40^{\mathrm{a}}$ & $59.80 \pm 0.40^{\mathrm{b}}$ \\
$\mathrm{WK}_{1}$ & $62.58 \pm 1.70$ & $63.89 \pm 1.44$ & $60.70 \pm 1.44$ \\
$\mathrm{WK}_{2}$ & $62.40 \pm 1.34$ & - & $60.04 \pm 1.13$ \\
\hline abc: means on the same row with different superscripts are significantly different (p<0.05). &
\end{tabular}

Significant differences in the response of laying hens to different moulting methods have been widely reported (Reddy et al., 2008; Aygun and Olgun, 2010; Santos et al., 2014). Generally, hens moulted by FD has higher rates of body weight loss, and decreases in egg production during moulting compared to non-fast moult treatments. The observed significantly lower body weight and HDEP of hens subjected to FD agrees with Reddy et al. (2008) and Aygun and Olgun (2010) who reported higher losses in body weight and egg production in layers subjected to 


\section{Response of domestic chickens to fasting and non-fast moulting programmes}

Table 4: Effect of moulting methods on performance traits of indigenous chickens during the moulting period

\begin{tabular}{llll}
\hline & $\mathrm{ZnO}$ & FD & Control \\
\hline Body weight (kg) & & & \\
Initial & $1.36 \pm 0.15$ & $1.38 \pm 0.10$ & $1.21 \pm 0.13$ \\
$\mathrm{WK}_{1}$ & $1.27 \pm 0.15$ & $1.05 \pm 0.10$ & $1.08 \pm 0.13$ \\
$\mathrm{WK}_{2}$ & $1.14 \pm 0.14$ & $0.93 \pm 0.09$ & $1.07 \pm 0.11$ \\
Egg production (\%) & & \\
Initial & $32.14 \pm 6.58^{\mathrm{b}}$ & $54.29 \pm 6.58^{\mathrm{a}}$ & $35.71 \pm 6.58^{\mathrm{ab}}$ \\
$\mathrm{WK}_{1}$ & $37.50 \pm 7.46$ & $22.86 \pm 7.46$ & $25.71 \pm 7.46$ \\
$\mathrm{WK}_{2}$ & $10.71 \pm 3.25^{\mathrm{b}}$ & $0.00 \pm 0.00^{\mathrm{c}}$ & $35.71 \pm 3.25^{\mathrm{a}}$ \\
Egg weight (g) & & & \\
Initial & $45.19 \pm 1.73$ & $41.60 \pm 1.73$ & $43.70 \pm 1.73$ \\
$\mathrm{WK}_{1}$ & $43.36 \pm 1.67$ & $42.10 \pm 2.21$ & $39.34 \pm 1.67$ \\
$\mathrm{WK}_{2}$ & $40.77 \pm 1.83$ & - & $39.34 \pm 1.69$ \\
\hline abc: means on the same row with different superscripts are significantly different $(\mathrm{p}<0.05)$. &
\end{tabular}

fasting moult compared to those fed different moulting diets as well as differences in the number of days to stoppage of lay. In the study by Reddy et al. (2008) Cornish and Rock layers fed high dietary $\mathrm{ZnO}$ stopped lay by $\mathrm{D} 25$ and 22 , respectively, while those subjected to fasting moult stopped egg production by $\mathrm{D}$ 14.

Effect of genotype on changes in performance traits during moulting of hens
Shaver brown hens moulted by $\mathrm{ZnO}$ had significantly $(\mathrm{p}<0.05)$ higher losses in body weight and HDEP in the first week of moulting as well as higher cummulative body weight loss compared to the indigenous chickens (Table 5) while changes in egg weight did not differ significantly between the genotypes. For hens moulted by FD (Table 6), changes in body weight, HDEP, and egg weight did not differ significantly between genotypes.

Table 5: Comparative change in performance of Shaver brown and local chickens during moulting by ZnO supplementation

\begin{tabular}{lll}
\hline & Shaver brown & Local chicken \\
\hline Body weight (kg) & $0.23 \pm 0.03(13.24)^{\mathrm{a}}$ & \\
$\mathrm{WK}_{0-1}$ & $0.05 \pm 0.03(3.14)$ & $0.09 \pm 0.05(5.75)^{\mathrm{b}}$ \\
$\mathrm{WK}_{1-2}$ & $0.28 \pm 0.03(16.35)$ & $0.13 \pm 0.04(9.39)$ \\
$\mathrm{WK}_{0-2}$ & & $0.21 \pm 0.06(14.65)$ \\
Egg production (\%) & $30.45 \pm 6.10(53.18)^{\mathrm{a}}$ & $-5.36 \pm 12.16(-55.24)^{\mathrm{b}}$ \\
$\mathrm{WK}_{0-1}$ & $24.79 \pm 6.93(74.78)$ & $26.79 \pm 10.71(48.81)$ \\
$\mathrm{WK}_{1-2}$ & $55.24 \pm 6.44(90.25)^{\mathrm{a}}$ & $21.43 \pm 3.57(72.86)^{\mathrm{b}}$ \\
$\mathrm{WK}_{0-2}$ & & \\
Egg weight $(\mathrm{g})_{\mathrm{WK}_{0-1}}$ & $-1.21 \pm 1.26(-1.95)$ & $1.83 \pm 1.66(3.76)$ \\
$\mathrm{WK}_{1-2}$ & $0.18 \pm 2.72(-0.05)$ & $1.98 \pm 2.75(3.88)$ \\
$\mathrm{WK}_{0-2}$ & $0.20 \pm 1.88(0.25)$ & $3.68 \pm 3.85(6.82)$ \\
\hline $\mathrm{WK}$ & & \\
\hline
\end{tabular}

WK: week; a, b: row means with different superscripts are significantly different $(\mathrm{p}<0.05)$; negative value indicates increase in trait value; values in parenthesis are percentages. 


\section{Ogbu, Ndifereke, Ogbu N.and Okoli}

Table 6: Comparative change in performance of Shaver brown and local chickens during moulting by feed deprivation

\begin{tabular}{lll}
\hline & Shaver brown & Local chicken \\
\hline Body weight (kg) & & \\
$\mathrm{WK}_{0-1}$ & $0.36 \pm 0.04(21.78)$ & $0.33 \pm 0.11(15.31)$ \\
$\mathrm{WK}_{1-2}$ & $0.17 \pm 0.03(12.71)$ & $0.12 \pm 0.04(7.27)$ \\
$\mathrm{WK}_{0-2}$ & $0.53 \pm 0.05(31.93)$ & $0.45 \pm 0.12(21.45)$ \\
Egg production (\%) & & \\
$\mathrm{WK}_{0-1}$ & $29.57 \pm 11.04(51.26)$ & $31.43 \pm 5.95(64.29)$ \\
$\mathrm{WK}_{1-2}$ & $28.57 \pm 11.15(71.43)$ & $22.86 \pm 9.18(57.14)$ \\
$\mathrm{WK}_{0-2}$ & $58.14 \pm 1.82(100.00)$ & $54.29 \pm 5.71(100.00)$ \\
Egg weight $(\mathrm{g})_{\mathrm{WK}_{0-1}}$ & \\
$\mathrm{WK}_{1-2}$ & $-1.40 \pm 1.07(-2.25)$ & $-0.85 \pm 1.52(-2.20)$ \\
$\mathrm{WK}_{0-2}$ & - & - \\
\hline WK: week; a, b: means on the same row with different superscripts are significantly different $(\mathrm{p}<0.05) ;$ negative value indictes an increase in \\
trait value; values in parenthesis are percentages.
\end{tabular}

Breed differences in response to moulting techniques reflect genetic differences in bird type. Reddy et al. (2008) reported a loss of $16 \%$ in body weight to end of egg production due to $\mathrm{ZnO}$ in Cornish layers compared to $21.74 \%$ in Rock layer, and $14.9 \%$ loss due to fasting in Cornish layers compared to $16.18 \%$ in Rock layers. The same authors reported that Cornish layers fed $\mathrm{ZnO}$ stopped laying by D 25 compared to D 22 for Rock layers. Santos et al. (2014) observed that among other factors, breed differences account for differences in response of layers to moulting methods.

\section{Conclusion}

Zinc supplementation at 20,000ppm in the diet of laying chickens as moulting agent is a milder but equally effective moulting method as fasting and is recommended for intensive commercial and rural indigenous poultry production.

\section{References}

Al-Kirkuki, S. M. S. 2012. Effect of forced molting by zinc oxide and the role of vitamin $\mathrm{C}$ on body weight and reentry to production of broiler breeder. Mesopotamia J. of Agric. 40 (2):9 18.
Aygun, A. and Olgun, O. 2010. The effect of non-feed and fed withdrawal molting methods on molt and post molt performance in laying hens. Trends in Animal and Veterinary Sciences Journal 1 (2): 45 - 48.

Berry 2003. The physiology of induced molting. Poultry Science 82: 971 980.

El-Deek, A. A. and Al-Harthi, M. A. 2004). Post molt performance parammeters of broiler breeder hens associated with molt induced by feed restriction, high dietary zinc and fasting. Int. J. of Poult. Sci. 3 (7): 456 -462 .

Gast, R. K. and Ricke, S. C. 2003. Symposium: Current and future prospects for induced moulting in laying hens. Poult. Sci. 82: 964.

Gjorgovska, N., Kiril, F., Vesna, L., Nedeljka, N. and Tosho, K. 2012. Egg shell quality of aged hens during the rejuvenation. Lucrari StiintificeSeria Zootechnie 58:277-280.

Holt, P. S. 2003. Molting and Salmonella enterica serovar Enteritidis infection: The problem and some solutions. Poult. Sci. 82:1008-1010.

Hussein, S. A. 1996. Induced moulting 


\section{Response of domestic chickens to fasting and non-fast moulting programmes}

procedures in laying fowl. World's

Poult. Sci. J. 52: 175-187.

Molino, A. B., Garcia, E. A., Berto, D. A., Pelicia, K., Sitra, A. P. and Vercese, F. 2009. The effects of alternative forced molting methods on the performance and egg quality of commercial layers. R. Bras. de Ciencia Avicola 11 (2): 109-113.

Moustafa, G. Z., Anwer, W. and Badawy, E. M. 2010. Effect of induced molting on performance of cob broiler breeders under field conditions. Arch. Geflugelk 74 (2): $87-93$

North, M.O. and Bell, D.D. 1990. Commercial chicken production manual. $4^{\text {th }}$ ed. Chapman Hall, New York.

Ogbu, N. N., Ogbu, C. C. and Ugwu, S. O. C. 2016. Effects of selection and zinc on biochemical constituents and quality of indigenous turkey semen. International Journal of Agricultural Innovation and Research 4 (5): 865871.

Park, S. Y., Birkhold, S. G., Kubena, L. F., Nisbet, D. J. and Ricke, S. C. 2004. Effect of high zinc diets using zinc propionate on moult induction, organs, and postmoult egg production and quality in laying hens. Poult. Sci. 83: 24-33.

Reddy, V., Malathi, V. K. and Venkatarami Reddy, B. S. 2008. Effect of induced molt in male and female line broiler breeder hens by zinc oxide and feed withdrawal methods on post molt performance parameters. Int. J. of Poult. Sci. 7 (6): $586-593$.

Ricke, S. C., Kwon, Y. M., Woodward, C. L., Byrd, J. A., Nibet, D. J. and Kubena, L. F. 2001. Limitation of Salmonella enteritidis colonization by diets containing low calcium and low zinc. Poultry Sci. 80 (1): 262 (Abstr.).

Santos, G. C., Garcia, E. A., Filho, J. A. V., Molino, A. B., Pelicia, K., Berto, D. A., Murakami, E. S. F. and Montenegro, A. T. 2014. Feed type for induced molting of commercial layer hens. Revista Brasileira de Zootecnia 43 (3):146-150.

Sgavioli, S., Filardi, R. S., Praes, M. F. F. M., Domingues, C.H. F., Andrade, P. C., Boleli, I. C. and Junqueira, $O$. M. 2013. Effect of forced-molting methods and rearing temperatures on the performance and organ biometrics of laying hens. Revista Brasileira de Ciência Avícola 15:239-245.

Sohail, H .K., Rehman, A. and Ansari, J. 2011. Effect of dietary minerals on post molt performance of laying hens. Vet. World 4 (9):389-395.

Webster, A.W. 2003. Physiology and behavior of the hen during induced moult. Poultry Sci. 82: 992-1002.

Yousaf, M. and Ahmad, N. 2006. Effects of Housing systems on productive performance of commercial layers following induced molting by aluminium oxide supplementation. Pakistan Vet. J. 26 (3): 101-104.

Received: $12^{\text {th }}$ August, 2018 Accepted: $9^{\text {th }}$ February, 2019 